\title{
Agro-biochemical Traits of Sugarcane Varieties Grown in the Brazilian Semi-arid Region
}

\author{
Ygor Herinque Leal ${ }^{1}$, Alexandre Tavares da Rocha ${ }^{2}$, Alexandre Campelo de Oliveria ${ }^{1}$, \\ Djalma Euzébio Simões Neto ${ }^{3}$, João Tiago Correia Oliveira ${ }^{2}$, Nathalia Bandeira Diniz ${ }^{1}$, \\ Keila Aperecida Moreira ${ }^{2} \&$ Sergio Luiz Ferreira da Silva ${ }^{1}$ \\ ${ }^{1}$ Master Program in Plant Science, Academic Unit of Serra Talhada, Federal Rural University of Pernambuco, \\ Serra Talhada, Pernambuco, Brazil \\ ${ }^{2}$ Academic Unit of Garanhuns, Federal Rural University of Pernambuco, Garanhuns, Pernambuco, Brazil \\ ${ }^{3}$ Sugarcane Experimental Station, Federal Rural University of Pernambuco, Carpina, Pernambuco, Brazil \\ Correspondence: Alexandre Tavares da Rocha, Academic Unit of Garanhuns, Federal Rural University of \\ Pernambuco, Av Bom Pastor, Boa Vista, Garanhuns, Pernambuco, Brazil. E-mail: altarocha@gmail.com
}

Received: December 5, 2018

Accepted: May 19, 2019 Online Published: July 31, 2019

doi:10.5539/jas.v11n11p106

URL: https://doi.org/10.5539/jas.v11n11p106

\begin{abstract}
The objective of this research was to evaluate the productive response associate to biochemical indicators and oxidative enzymes activities involved in the water deficit resistance in eight sugarcane varieties (RB951541, RB931011, RB962962, RB867515, RB763710, RB72454, RB863129, and RB92579) grown in the semi-arid regions of Brazil. Compared to all other varieties, RB763710 was superior in the number of stems $\mathrm{m}^{-1}$, mean height, and stem diameter, production of whole plant fresh biomass and stem. When biochemical responses were obtained, all sugarcane varieties had a statistically similar solubility and maturity, regardless of the specific maturity rate of each cultivar. The increase in soluble carbohydrate levels occurred in the most stress-sensitive varieties and the variety RB763710 had the highest proline content. A lower general correlation was observed between the production of fresh biomass of stalks and the enzymatic activity. Among the varieties, RB763710 had the highest enzymatic activities which possibly provided greater tolerance to water stress due to the ability to maintain the redox state in the leaves of plants under water deficit. The study of the adaptation mechanisms of sugarcane against water deficit has contributed to the development and diffusion of genotypes tolerant to rainfed conditions, thus contributing to increased productivity even under adverse conditions, allowing maintenance and optimization of the production chains of sugarcane in rainfed regions.
\end{abstract}

Keywords: Saccharum spp., water stress, enzymatic activity

\section{Introduction}

The economic, social and energy valorization of sugarcane (Saccharum officinarum L.) has promoted its cropping even in unfavorable and semi-arid regions due to its diverse uses such as energy matrix, sugar-alcohol, animal production and civil construction. Semi-arid regions have several conditions that can limit crop productivity such as water deficit, high temperatures, soil salinity and high luminosity (Choudhary et al., 2018; Pedroso et al., 2018).

Water stress is one of the main factors that reduces crop productivity (Ferreira et al., 2017; González-Chavira et al., 2018). Other types of stress are triggered as a consequence of water stress such as oxidative stress (due to reduced photosynthesis and increased respiration). Oxidative stress can increase the production of reactive oxygen species, such as singlet oxygen, hydrogen peroxide, superoxide and radical hydroxyl groups, which are capable of damaging vital cell structures and organelles, culminating in cell death, depending on the severity of the stress (Iqba et al., 2018).

As a defense mechanism against unfavorable conditions, plants produce antioxidant enzymes and other non-enzymatic compounds that are able to neutralize the damage caused due to stress (Jiang et al., 2016; Marcos et al., 2018). Antioxidative enzymes include catalase, superoxide dismutase, ascorbate peroxidase, polyphenoloxidase, peroxidase and glutathione reductase (Moura et al., 2018). 
Several techniques can be used to identify crop varieties that are more drought resistant as well as others abiotic factors; simpler techniques such as through agronomic evaluations and sophisticated ones such as harness sing the biochemical characteristics of the plant and its enzymatic activity, which signal a possible tolerance of the crop to stress (Marcos et al., 2018). Evaluations of the antioxidative system have greatly aided in genetic improvement programs, as well as the identification of promising drought-tolerant genotypes (Hellal et al., 2018; Iqbal et al., 2018).

In this context, the study of the adaptation mechanisms of sugarcane to water stress has contributed to the development of tolerant genotypes capable of reducing productivity variation even under adverse conditions (Boaretto et al.; 2014; Marcos et al., 2018), making it possible to maintain and optimize sugarcane production chains in rainfed regions. We therefore aimed to evaluate the productive response associate to biochemical indicators and oxidative enzymes activities involved in the drought resistance in eight sugarcane varieties (RB951541, RB931011, RB962962, RB867515, RB763710, RB72454, RB863129, and RB92579) growing under natural semiarid conditions of Brazil, characterized by the water deficit cycles that severely affect the crop yield.

\section{Methods}

The experiment was conducted in field, under natural environment conditions of Brazilian semiarid in the period from february to october 2015 , in the municipality of Triunfo (Latitude: $7^{\circ} 53^{\prime} 14.77^{\prime \prime} \mathrm{S}$; longitude: $38^{\circ} 6^{\prime} 49.18^{\prime \prime}$ W; altitude: $535.5 \mathrm{~m}$ ), Pernambuco, Brazil. The climate, according to the classification of Köppen-Geiger (1928) is of the type BSh i.e., hot semi-arid. The average precipitation and temperature were $501.71 \mathrm{~mm}$ and $25.9^{\circ} \mathrm{C}$, respectively in 2015. During the study, plants were watered only by the rainfall with mean values relatively lower to required by culture, mainly in the months jun, july and august that presented precipitations by $25.03 \mathrm{~mm}$, $24.34 \mathrm{~mm}$ and $25.13 \mathrm{~mm}$, respectively. This volume of water provided by the rainfall is relatively lower than the demand required by the sugarcane, which should be around $1700 \mathrm{~mm}$ per year (Silva et al., 2012). Thus, it is worth noting that was not employed specific treatment for the water stress with different water levels. However, the plants were exposed to a water restriction during its growth cycle.

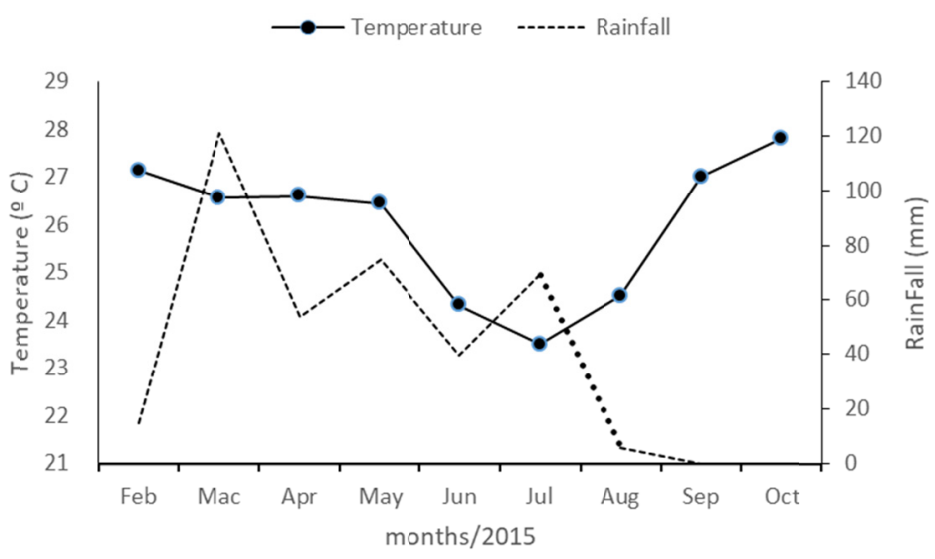

Figure 1. Average air temperature and rainfall in the municipality of Triunfo, Pernambuco, Brazil, from February to October 2015

The experiment was conducted as a randomized block design consisting of eight sugarcane varieties and three replicates. The experimental units ( $9 \mathrm{~m}$ long with $1 \mathrm{~m}$ spacing) were composed of four grooves with a total area of $36 \mathrm{~m}^{2}$ consisted of two commonly known grasses Andropogon gayanus and Urochloa mosambicensis which presented an intermediate stage of degradation. Soil samples $(0.2 \mathrm{~m} \times 0.2-0.4 \mathrm{~m}$ depth) were characterized chemically according to the recommendation by EMBRAPA (2011) (Table 1). 
Table 1. Chemical characterization of the soil of the experimental area located in the municipality of Triunfo, Pernambuco, Brazil

\begin{tabular}{|c|c|c|c|c|c|c|c|c|c|}
\hline Depth & $\mathrm{pH}\left(\mathrm{H}_{2} \mathrm{O}\right)$ & $\mathrm{P}$ & $\mathrm{K}^{+}$ & $\mathrm{Na}^{+}$ & $\mathrm{Ca}^{2+}$ & $\mathrm{Mg}^{2+}$ & $\mathrm{Al}^{3+}$ & $\mathrm{H}+\mathrm{Al}$ & S.B \\
\hline & & $\mathrm{mg} \mathrm{dm}^{-3}$ & ----- & $-\cdots$ & --------- & $\mathrm{cmol}_{\mathrm{c}}$ & 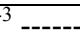 & ----. & ----------" \\
\hline $0.0-0.2 \mathrm{~m}$ & 6.3 & 21.0 & 0.4 & 0.0 & 4.7 & 0.9 & 0.0 & 0.0 & 6.0 \\
\hline $0.2-0.4 \mathrm{~m}$ & 6.4 & 17.0 & 0.3 & 0.0 & 4.2 & 0.4 & 0.0 & 0.0 & 4.9 \\
\hline \multirow[t]{2}{*}{ Depth } & CTC & $\mathrm{m}$ & $\mathrm{V}$ & $\mathrm{C}$ & M.O. & $\mathrm{Fe}^{2+}$ & $\mathrm{Cu}^{2+}$ & $\mathrm{Zn}^{2+}$ & $\mathrm{Mn}^{2+}$ \\
\hline & $\mathrm{cmol}_{\mathrm{c}} \mathrm{dm}^{-3}$ & \multicolumn{2}{|c|}{---------- \% --------- } & \multicolumn{2}{|c|}{----- $\mathrm{g} \mathrm{kg}^{-1}$----- } & ----- & $-\cdots--1$ & $\mathrm{dm}^{-3}--$ & --------- \\
\hline $0.0-0.2 \mathrm{~m}$ & 7.0 & 0.2 & 85.0 & 0.8 & 1.5 & 165.5 & 0.8 & 21.0 & 34.0 \\
\hline $0.2-0.4 \mathrm{~m}$ & 5.5 & 0.2 & 90.0 & 0.6 & 1.1 & 160.5 & 1.9 & 11.0 & 106.0 \\
\hline
\end{tabular}

Note. S.B: Sum of bases; C.E.C: Cation exchange capacity; O.M.: Organic matter.

For plantation, plowing, and furrowing with a spacing of $1.0 \mathrm{~m}$ and approximately $0.3 \mathrm{~m}$ deep was performed. According to the results of the soil analysis, the experimental site was fertilized with 181,142 , and $134 \mathrm{~kg} \mathrm{ha}^{-1}$ of urea, triple superphosphate, and potassium chloride, respectively based on the Manual of Recommendations for Fertilization for the State of Pernambuco (IPA, 1998). The planting of sugarcane was carried out by the "foot with tip method, using stems sectioned in smaller tops containing three to four buds, aiming at greater uniformity of the plants.

The evaluated varieties were RB951541, RB931011, RB962962, RB867515, RB763710, RB72454, RB863129, and RB92579 chosen for having great representativity in the semi-arid region of Pernambuco (RIDESA, 2010) (Table 2). The sugarcane seeds were obtained from the Agronomic Institute of Pernambuco, Carpina Sugarcane Experimental Station in agreement with the Interuniversity Network for the Development of the Sugarcane Sector.

Table 2. General characteristics of the eight sugarcane varieties (Saccharum officinarum L.) to be evaluated agronomically and biochemically

\begin{tabular}{llllllll}
\hline Cultivar & AP & GR & GH & MA & RCE & SC & FC \\
\hline RB951541 & Averege & Fast & Erect & Precocious & Not & High & Averege \\
RB931011 & Averege & Fast & Erect & Iate & Averege & High & Averege \\
RB962962 & High & Fast & Erect & Iate & Not & High & Averege \\
RB867515 & High & Fast & Erect & Iate & Averege & High & Averege \\
RB763710 & High & Fast & Semi-decumbent & Iate & Not & Averege & Averege \\
RB72454 & High & Regular & Erect & Iate & Not & High & Averege \\
RB863129 & High & Regular & Semi-decumbent & Averege & Not & Averege & Averege \\
RB92579 & High & Slow & Semi-decumbent & Iate & Averege & High & Averege \\
\hline
\end{tabular}

Note. AP: Agricultural productivity; GR: Growth rate; GH: Growth habit; MA: Maturation; RCE: Restriction to the culture environment; SC: Sucrose content; FC: Fiber content.

Source: RIDESA (2010).

Sugarcane planting, measurements, and collection of plant material for production, soluble solids content, and biochemical characteristics were carried out in October 2015. At the study site, the number of plants, stems $\mathrm{m}^{-1}$, average stem height $[(n=10)$ measured at soil level to the sheath of the first leaf $(+1)]$ and the stem diameter was measured as per Hermann and Câmara (1999). The production of fresh biomass of the stem and entire plant was obtained by weighing the plants present at the study site and expressed as $\mathrm{mg} \mathrm{ha}^{-1}$.

The content of soluble solids (Brix) was evaluated from the sugarcane juice extracted from the internodes of the second and third stem base, end of the stem, penultimate and antepenultimate internodes, and from the entire stem, enabling the monitoring of the maturity index of sugarcane. The broth was extracted with the aid of a mill. Following grinding, the broth was filtered $(0.053 \mathrm{~mm}$ sieve $)$ to remove bagasse and impurities. A bench refractometer (ABBE-ART-100) was used to determine the Brix using two drops on the refractometer prism.

The leaf samples were collected from the leaves without ribs, frozen in liquid nitrogen and kept at $-80{ }^{\circ} \mathrm{C}$ for future biochemical analyses of soluble carbohydrates $\left(\mathrm{CHO}_{\mathrm{sol}}\right)$, proline $(\mathrm{PL})$ and enzymatic activity. The extraction and determination of $\mathrm{CHO}_{\text {sol }}$ was performed according to Dubois et al. (1956) with modifications: 0.05 
$\mathrm{g}$ of the frozen material was macerated in $1.3 \mathrm{~mL}$ of distilled water and the extract centrifuged at $12,000 \times \mathrm{g}$ for $21 \min$ at $4{ }^{\circ} \mathrm{C}$.

Subsequently, $25 \mu \mathrm{L}$ of the supernatant was diluted in a solution containing $475.0 \mu \mathrm{L}$ of distilled water, $500.0 \mu \mathrm{L}$ of $5 \%$ phenol, and $2.5 \mathrm{~mL}$ of concentrated sulfuric acid. After standing for $10 \mathrm{~min}$, the solution was stirred for a few seconds and then allowed to stand again for $20 \mathrm{~min}$ in beakers containing water at room temperature $\left(25^{\circ} \mathrm{C}\right)$. The readings were recorded using a spectrophotometer at $490 \mathrm{~nm}$. The $\mathrm{CHO}_{\text {sol }}$ content was calculated from a standard curve prepared with $180 \mu \mathrm{g} \mathrm{mL}^{-1}$ glucose and the results were expressed as mg g${ }^{-1}$ fresh leaf mass (FLM).

The extraction and determination of proline (PL) was performed according to a modified method described by Bates (1973). Fresh leaf tissues $(0.5 \mathrm{~g})$ were weighed from the central region of the leaf blade, without the ribs and packed in $10 \mathrm{~mL}$ of distilled water, followed by placing it in a bath for $1.0 \mathrm{~h}$ at $100{ }^{\circ} \mathrm{C}$. The extracts were then filtered twice using Whatman ${ }^{\circledR}$ qualitative filter paper. A $1 \mathrm{~mL}$ aliquot of the filtrate, $1 \mathrm{~mL}$ of acidic ninhydrin $\left(1.25 \mathrm{~g} \mathrm{~L}^{-1}\right.$ ninhydrin, $30 \mathrm{ml} \mathrm{L}^{-1}$ of glacial acetic acid, and $20 \mathrm{ml} \mathrm{L}^{-1}$ of $6 \mathrm{M}$ phosphoric acid) were added in a container with lids along with $1 \mathrm{~mL}$ of glacial acetic acid. The solution was homogenized and placed in the water bath for $1 \mathrm{~h}$ at $100{ }^{\circ} \mathrm{C}$ and then in an ice bath for $15 \mathrm{~min}$ to interrupt the reaction.

After reaching room temperature, $2 \mathrm{~mL}$ of toluene was added and the solution was homogenized for 15 seconds. After $30 \mathrm{~min}$ of homogenization, the spectrophotometer readings were recorded at $520 \mathrm{~nm}$. For quantification of the free proline, a standard curve was prepared using proline. The results were expressed in $\mu \mathrm{mol} \mathrm{g}^{-1}$ FLM.

For the enzymatic activities the foliar extract was obtained according to methodology proposed by Silva (1981) and Simões et al. (2015). Estimates of the enzymatic activity of peroxidase were performed using the method described by Urbanek, Kuzniak-Gebarowska, and Herka (1991), using guaiacol and $\mathrm{H}_{2} \mathrm{O}_{2}$ as substrates. The activity of the polyphenoloxidase was verified by the oxidation of pyrogallol according to Kar and Mishra (1976) and the catalase activity measured according to the recommendations of Havir and Mchale (1987). Superoxide dismutase activity was measured by using the method proposed by Giannopolitis and Ries (1977), and Beauchamp and Fridovich (1971). The enzymatic activities were expressed in U.A. $\min ^{-1} \mathrm{~g}^{-1}$ FLM.

The data obtained from productivity, biochemistry, and enzymatic activity were subjected to tests of normality, homoscedasticity, and analysis of variance. The averages were compared by the Scott-Knott test $(\mathrm{p} \leq 0.05)$, using SISVAR software 5.6. In addition, Pearson's correlation between general production data, and proline and enzymatic activities was performed. Log-transformed data was used to construct the scatter plot by main coordinate analysis obtained on the basis of the similarity matrix of the Jaacard Coefficient using PAST 1.9 software.

\section{Results}

The sugarcane variety RB763710 was significantly superior in all agronomic variables such as the number of stems $\mathrm{m}^{-1}$, mean height, and main stem diameter, production of whole plant fresh biomass and stem, followed by RB962962, RB867515, and RB72454 (Table 3).

Table 3. Production characteristics of different sugarcane varieties (Saccharum officinarum) grown in the rainfed conditionsbetween February and October 2015, Triunfo, Pernambuco, Brazil

\begin{tabular}{lllllc}
\hline Sugarcane varieties & NSM & MHS & MSD & PFB & FBS \\
\hline & m linear & m & cm & ---------- Mg ha $^{-1}----------$ \\
RB951541 & $22.000 \mathrm{~b}$ & $0.904 \mathrm{~b}$ & $2.695 \mathrm{~b}$ & $138.093 \mathrm{c}$ & $106.036 \mathrm{c}$ \\
RB931011 & $18.000 \mathrm{c}$ & $0.868 \mathrm{~b}$ & $2.665 \mathrm{~b}$ & $89.750 \mathrm{~d}$ & $72.446 \mathrm{~d}$ \\
RB962962 & $23.666 \mathrm{~b}$ & $1.259 \mathrm{a}$ & $3.046 \mathrm{a}$ & $208.753 \mathrm{~b}$ & $166.291 \mathrm{~b}$ \\
RB767515 & $22.000 \mathrm{~b}$ & $1.270 \mathrm{a}$ & $2.792 \mathrm{~b}$ & $187.060 \mathrm{~b}$ & $134.266 \mathrm{~b}$ \\
RB72454 & $27.333 \mathrm{a}$ & $1.139 \mathrm{a}$ & $3.045 \mathrm{a}$ & $267.130 \mathrm{a}$ & $208.160 \mathrm{a}$ \\
RB863129 & $23.666 \mathrm{~b}$ & $0.876 \mathrm{~b}$ & $3.201 \mathrm{~b}$ & $186.900 \mathrm{~b}$ & $138.055 \mathrm{~b}$ \\
RB92579 & $17.000 \mathrm{c}$ & $1.332 \mathrm{a}$ & $2.717 \mathrm{a}$ & $156.406 \mathrm{c}$ & $117.068 \mathrm{c}$ \\
CV $(\%)$ & $23.000 \mathrm{~b}$ & $1.002 \mathrm{~b}$ & $2.526 \mathrm{~b}$ & $157.696 \mathrm{c}$ & $118.155 \mathrm{c}$
\end{tabular}

Note. NSM: Number of stems per linear meter; MHS: Mean height of stem; MSD: Main stem diameter; PFB: Production of whole plant fresh biomass; FBS: Production of fresh biomass of stem. The averages followed by the same letter in the column do not differ by Scott-Knott's test at 5\% probability. 
The varieties with the highest number of shoots $\mathrm{m}^{-1}$ and the diameter of the main stem showed the highest yields of fresh whole plant biomass and height (Table 3), a fact proven when evaluating the correlation between the variables (Table 4).

All evaluated varieties of sugarcane presented Brix and similar maturity index (Figure 2), independent of the specific maturation rate of each cultivar (Table 2). The increase in soluble carbohydrate levels occurred in the most stress-sensitive varieties and the variety RB763710 was highlighted in proline production (Table 5).

Table 4. Correlation of production variables of sugarcane varieties (Saccharum officinarum) RB951541, RB931011, RB962962, RB867515, RB763710, RB72454, RB863129 and RB92579 cultivated under rainfed conditions between February and October 2015, Triunfo, Pernambuco Brazil

\begin{tabular}{lllll}
\hline Variables & MHS & MSD & PFB & FBS \\
\hline NSM & -0.049 & -0.264 & $0.815^{*}$ & $0.820^{*}$ \\
MSD & & 0.071 & 0.462 & 0.443 \\
PBF & & & $0.671^{*}$ & $0.676^{*}$ \\
FSB & & & $0.992^{*}$ \\
\hline
\end{tabular}

Note. NSM: Number of stems per linear meter; MHS: Mean height of stem; MSD: Main stem diameter; PFB: Production of whole plant fresh biomass; FBS: Production of fresh biomass of stem. * Significant correlation at the $5 \%$ level.

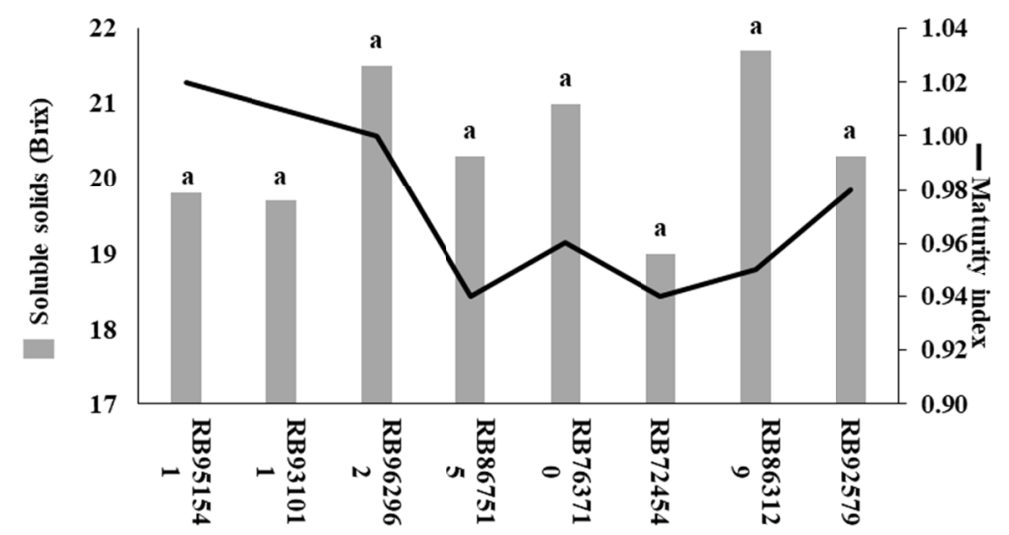

Figure 2. Soluble solids ( ${ }^{\circ}$ Brix) and maturation index of different sugarcane varieties (Saccharum officinarum) cultivated in the dry season between February and October 2015, Triunfo, Pernambuco, Brazil

Table 4. Biochemical characteristics and enzymatic activity of different sugarcane varieties (Saccharum officinarum) cultivated in the dry season between February and October 2015, Triunfo, Pernambuco, Brazil

\begin{tabular}{|c|c|c|c|c|c|c|}
\hline Sugarcane varieties & $\mathrm{CHO}_{\text {sol }}$ & PL & POD & PPO & CAT & SOD \\
\hline & $\mathrm{mg} \mathrm{g}^{-1} \mathrm{MFF}$ & $\mu \mathrm{mol} \mathrm{g}^{-1} \mathrm{MFF}$ & \multicolumn{4}{|c|}{ 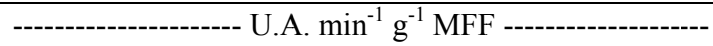 } \\
\hline RB951541 & $2.380 \mathrm{a}$ & $0.122 \mathrm{c}$ & $1.005 \mathrm{~d}$ & $1.406 \mathrm{~b}$ & $0.017 \mathrm{c}$ & $31.937 \mathrm{a}$ \\
\hline RB931011 & $2.309 \mathrm{a}$ & $0.374 \mathrm{a}$ & $0.945 \mathrm{~d}$ & $1.630 \mathrm{~b}$ & $0.002 \mathrm{e}$ & $32.253 \mathrm{a}$ \\
\hline RB962962 & $2.388 \mathrm{a}$ & $0.296 \mathrm{~b}$ & $0.952 \mathrm{~d}$ & $1.382 \mathrm{~b}$ & $0.014 \mathrm{c}$ & $25.897 \mathrm{c}$ \\
\hline RB867515 & $2.028 \mathrm{a}$ & $0.097 \mathrm{c}$ & $1.290 \mathrm{c}$ & $1.754 \mathrm{~b}$ & $0.011 \mathrm{c}$ & $28.976 \mathrm{~b}$ \\
\hline RB763710 & $2.106 \mathrm{a}$ & $0.345 \mathrm{a}$ & $1.724 \mathrm{a}$ & $2.714 \mathrm{a}$ & $0.040 \mathrm{a}$ & $31.977 \mathrm{a}$ \\
\hline RB72454 & $2.340 \mathrm{a}$ & $0.079 \mathrm{c}$ & $1.128 \mathrm{c}$ & $1.165 \mathrm{~b}$ & $0.034 \mathrm{~b}$ & $32.881 \mathrm{a}$ \\
\hline RB863129 & $2.336 \mathrm{a}$ & $0.342 \mathrm{a}$ & $1.160 \mathrm{c}$ & $1.597 \mathrm{~b}$ & $0.017 \mathrm{c}$ & $31.147 \mathrm{a}$ \\
\hline RB92579 & $2.248 \mathrm{a}$ & $0.263 \mathrm{~b}$ & $1.446 \mathrm{~b}$ & $1.647 \mathrm{~b}$ & $0.012 \mathrm{c}$ & $29.726 \mathrm{~b}$ \\
\hline CV (\%) & 3.56 & 9.43 & 7.41 & 7.47 & 12.45 & 14.89 \\
\hline
\end{tabular}

Note. $\mathrm{CHO}_{\text {sol }}$ : Soluble carbohydrates; PL: Proline; POD: Peroxidase; PPO: Polyphenoloxidase; CAT: Catalase; SOD: Superoxide dismutase. Means followed by the same letter in the column do not differ by Scott-Knott's test at $5 \%$ probability. 
Low overall correlation was observed between fresh shoot biomass production and enzymatic activity (Table 5). Among all the sugarcane varieties, RB763710 obtained the highest biomass yields and showed the highest enzymatic activities (Table 5), differing in similarity of the other cultivars when evaluating proline production and enzymatic activity (Figure 3).

Table 5. Correlation of the biochemical variables and enzymatic activity with the production of sugarcane varieties (Saccharum officinarum) RB951541, RB931011, RB962962, RB867515, RB763710, RB72454, RB863129 and RB92579 cultivated in the dry season between the months of February to October 2015, Triunfo, Pernambuco, Brazil

\begin{tabular}{llllll}
\hline Variables & PL & POD & PPO & CAT & SOD \\
\hline FSB & $0.899^{*}$ & 0.090 & 0.128 & 0.030 & 0.524 \\
PL & & $0.756^{*}$ & 0.255 & $0.696^{*}$ & $0.853^{*}$ \\
POD & & 0.012 & 0.139 & $0.722^{*}$ \\
PPO & & & 0.316 & $0.738^{*}$ \\
CAT & & & & 0.374
\end{tabular}

Note. FSB: Fresh stalk biomass; PL: Proline; POD: Peroxidase; PPO: Polyphenoloxidase; CAT: Catalase; SOD: Superoxide dismutase. * Significant correlation at the $5 \%$ level.

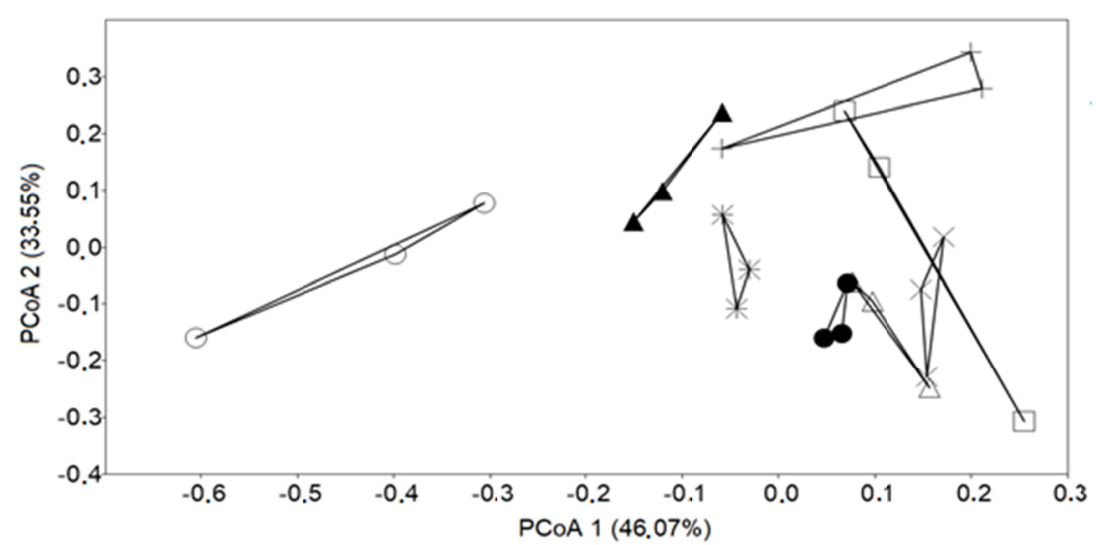

Figure 3. Principal coordinate analysis (CPoA) obtained from the similarity matrix based on the Jaccard Coefficient, estimated on the basis of proline production and peroxidase, polyphenoloxidase, catalase and superoxide dismutase activity of sugarcane varieties (Saccharum officinarum) $\times$ : RB951541; $\Delta$ : RB931011; 口: RB962962; $\boldsymbol{\Delta}$ : RB867515; ○: RB763710, +: RB72454, •: RB863129 and *RB92579 cultivated under dry season between February and October 2015, Triunfo, Pernambuco, Brazil

\section{Discussion}

Water deficit represent major environmental factor restrictive for crop yield, adverse effect that occur mainly in semiarid areas. When exposed to natural precipitation under field conditions the plants experience periods of water stress due to natural rain cycles. During these water deficit cycles may occur several metabolic disturbances related to key physiological processes necessary to yield, such as water relations, nutrient unbalance and photosynthesis ( $\mathrm{Li}$ et al., 2018). This disturbances can affect plant growth and development as well as induced secondary damages like as oxidative stress, compromising index relative to crop quality and yield (Kumar et al., 2019). Thus, the understanding of how the water deficit should affect production components associated with key metabolic processes, may be essential to adopt corrective strategies of these damages for crop under field conditions.

Genetic resistance to drought stress in plants is a multigenic character, considered relatively complex by involve a net metabolic process necessary to maintain growth under conditions of water deficit. Thus, the identification and exploitation of varieties that are more resistant to drought represent a viable strategy for obtaining crops that are more resistant to drought. In the presente study, varieties different sugarcane were cultivate under field conditions and evaluated relative its growth capacity associate to oxidative protection efficiency during relative water deficit. The sugarcane varieties RB763710, RB962962, RB867515, and RB72454 are characterized by 
high productivity and rapid growth however the variety RB763710 showed the highest average plant height even under water stress conditions, which has a semi-decumbent growth habit. The results observed in this study corroborate with those found by Silva et al. (2011), and Oliveira et al. (2015) that showed stem diameters of 2.450 and $2.486 \mathrm{~cm}$ for the varieties RB 92579 and RB72454, respectively. In both studies, the varieties were subjected to water stress, similar to this current study.

It should be emphasized that the maturity indices found in this current study represent sugarcane maturity according to the classification of Cesnik and Miocque (2004). Oliveira et al. (2011), and Cardozo and Sentelhas (2013) showed the negative influence of increased water availability on these varieties; hence, sugarcane plants submitted to rainfed conditions tend to accelerate their maturation.

Sales et al. (2012) showed that the $\mathrm{CHO}_{\text {sol }}$ contents remained constant for the tested varieties and their performance in the deterioration of the starch reserves of the plant when water stressed. Patade et al. (2011) found results different from those observed in this study (Table 4), where there was an increase in the levels of $\mathrm{CHO}_{\text {sol }}$ in the varieties more sensitive to stress (water and salinity).

Proline has been shown to have a strong correlation with increased drought tolerance (Balestro et al., 2017; Castañeda et al., 2018). However, Mansour and Ali (2017), and Marcos et al. (2018) argued that since proline is produced under stressful conditions, its absence or low production by the plant may indicate less stress.

The accumulation of proline in plant tissues is associated with a reduction in the concentration of toxic ions and the increase of water volume in the cytosol, besides protecting the cell membranes from oxidative stress (Merwad et al., 2018). Proline has been shown to decrease the osmotic potential and, consequently, maintain water and cell turgescence potential near adequate levels, being extremely important for the growth and development of plant tissues (Jungklang et al., 2017; De la Torre-González et al., 2018).

The low correlation between fresh stem biomass production and enzymatic activity in the present study may have been due to the greater tolerance to water stress as a consequence of the ability to maintain the redox state in the leaves of plants under water deficit.

Peroxidase integrates the oxidoreductase group, which catalyzes a large number of oxidative reactions, using peroxide as a substrate, or in some cases oxygen as a hydrogen acceptor; a process of high importance for the adaptation of plants to water stress (Freitas et al., 2008) as also observed in this current study with sugarcane.

Polyphenoloxidase is an enzyme that catalyzes the oxidation reaction of phenols in quinones, acting in an aerobic environment, located in the plastids (Kuwabara \& Katoh, 1999). The action of polyphenoloxidase reduces the amount of superoxide, causing oxidative damage in the plants, thus being an indicative of varieties tolerant to water restriction. However, the responses may vary between cultivars, species, tissues analyzed, duration and the magnitude of stress (Campos et al., 2004).

Superoxide dismutase plays an important role in the adaptation and survival of stressed plants, and the first line of defense against reactive oxygen species forming superoxide for hydrogen peroxide, generating lower levels of lipid peroxidation (Scandalios, 2005; Amaro, 2018). Superoxide produced in excess as a result of the stress caused by the water restriction, is extremely reactive and can be transformed into a hydroxyl radical, which is the most harmful of all the radicals, with the capacity to lead to deleterious changes in primary and secondary metabolism and mutations, leading to cell death and in high severity, plant death (Vranova et al., 2002).

The catalase enzyme has amain auxiliary function in the ascorbato-glutathione cycle, acting toward the detoxification caused by the hydrogen peroxide, in the cells of the plants (Sheikh-Mohamadi et al., 2018). Catalase activity increases according to the amount of hydrogen peroxide within the cells (Kumar et al., 2018). The values observed in this current study were low because sugarcane is a $\mathrm{C} 4$ plant possessing minimum photorespiratory ability; contrastingly $\mathrm{C} 3$ plants are more involved in the removal of hydrogen peroxide (Tolbert et al., 1969). Benesová et al. (2012) observed that the variety more tolerant to water stress had greater catalase activity and vice versa thus corroborating with the results observed in this current study.

Water deficit is one of the main factors against crop production (Ferreira et al., 2017), but not the only one, since other types of stress are capable of causing damage and organicity, cellular (Maia et al., 2012). Aiming at favorable conditions, plants may produce several antioxidant enzymes and other non-enzymatic compounds that seek to neutralize stress-induced damage (Cia et al., 2012; Marcos et al., 2018).

The results showed interspecific differences in the agronomic performance and the physiological responses of the studied cultivars. The variables that obtained the best tolerance to drought were those selected by slow maturation and fast growth rate. This pattern indicates the need for adjustments in the period of planting, 
management and cultivation time in a semi-arid environment, aiming at the supply of water during periods of high water demand, considering the expected product, fiber, biomass or sugar.

\section{References}

Amaro, A. C. E., Ramos, A. R. P., Macedo, A. C., Ono, E. O., \& Rodrigues, J. D. (2018). Effects of the fungicides azoxystrobin, pyraclostrobin and boscalid on the physiology of Japanese cucumber. Scientia Horticulturae, 228, 66-75. https://doi.org/10.1016/j.scienta.2017.10.016

Balestro, G. C., Higashi, B., Lopes, S. M. S., Gonçalves, J. E., Vieira, L. G. E., de Oliveira, A. J. B., \& Gonçalves, R. A. C. (2017). Biochemical composition of symplastic sap from sugarcane genetically modified to overproduce proline. Plant Physiology and Biochemistry, 113, 133-140. https://doi.org/ 10.1016/j.plaphy.2017.02.010

Bates, L. S., Waldren, R. P., \& Teare, I. D. (1973). Rapid determination of free proline for water-stress studies. Plant and Soil, 39, 205-207. https://doi.org/10.1007/BF00018060

Beauchamp, C. E., \& Fridovich, I. (1971). Superoxide dismutase: Improved assay applicable to acrylamide gels. Anal Biochem, 44, 276-287. https://doi.org/10.1016/0003-2697(71)90370-8

Benešová, M., Holá, D., Fischer, L., Jedelský, P. L., Hnilička, F., \& Wilhelmová, N. (2012). The Physiology and Proteomics of Drought Tolerance in Maize: Early Stomatal Closure as a Cause of Lower Tolerance to Short-Term Dehydration? PLoS ONE, 7(6), e38017. https://doi.org/10.1371/journal.pone.0038017

Boaretto, L. F., Carvalho, G., Borgo, L., Creste, S., Landell, M. G. A., Mazzafera, P., \& Azevedo, R. A. (2014). Water stress reveals differential antioxidant responses of tolerant and non-tolerant sugarcane genotypes. Plant Physiology and Biochemistry, 74, 165-175. https://doi.org/10.1016/j.plaphy.2013.11.016

Campos, A. D., Ferreira, A. G., Hampe, M. M. V., Antunes, I. F., Brancão, N., Silveira, E. P., ... Augustin, E. (2004). Atividade de peroxidase e polifenoloxidase na resistência do feijão à antracnose. Pesquisa Agropecuária Brasileira, 39, 637-643. https://doi.org/10.1590/S0100-204X2004000700004

Cardozo, N. P., \& Sentelhas, P. C. (2013). Climatic effects on sugarcane ripening under the influence of cultivars and crop age. Scientia Agricola, 70, 449-456. https://doi.org/10.1590/S0103-90162013000600011

Castañeda, V., de laPeña, M., Azcárate, L., Aranjuelo, I., \& Gonzalez, E. M. (2018). Functional analysis of the taproot and fibrous roots of Medicago truncatula: Sucrose and proline catabolism primary response to water deficit. Agricultural Water Management, 216, 473-483. https://doi.org/10.1016/j.agwat.2018.07.018

Cesnik, R., \& Miocque, J. (2004). Melhoramento da cana-de-açúcar (p. 307). Brasília: Embrapa. Retrieved from https://www.bdpa.cnptia.embrapa.br/consulta/busca?b=pc\&id=14238\&biblioteca=vazio\&busca=assunto:Se mente $\&$ FFacets $=$ assunto:Semente $\&$ sort $=\&$ paginacao $=t \&$ paginaAtual $=296$

Choudhary, A. K., Sultana, R., Vales, M. I., Saxena, K. B., Kumar, R. R., \& Ratnakumar, P. (2018). Integrated physiological and molecular approaches to improvement of abiotic stress tolerance in two pulse crops of the semi-arid tropics. Crop Science, 6(2), 99-114. https://doi.org/10.1016/j.cj.2017.11.002

De la Torre-González, A., Montesinos-pereira, D., Blasco, B., \& Ruiz, J. (2018). Influence of the proline metabolism and glycine betaine on tolerance to salt stress in tomato (Solanum lycopersicum L.) comercial genotypes. Journal of Plant Physiology, 231, 329-33. https://doi.org/10.1016/j.jplph.2018.10.013

Dubois, M., Gilles, K. A., Hamilton, J. K., Rebers, P. A., \& Smith, F (1956). Colorimetric method for determination of sugars and related substances. Analytical Chemistry, 28, 350-356. https://doi.org/10.1021/ ac60111a017

EMBRAPA. (2011). Manual de métodos de análise de solos (2nd ed., p. 230). Rio de Janeiro, Embrapa Solos.

Freitas, A. A., Francelin, M. F., Hirata, G. F., Clemente, E., \& Schmidt, F. (2008). Atividades das enzimas peroxidase (POD) e polifenoloxidase (PPO) nas uvas das cultivares benitaka e rubi e em seus sucos e geléias. Ciência e Tecnologia de Alimentos, 28(1), 172-177. https://doi.org/10.1590/S0101-20612008 000100025

Ferreira, T. H. S., Tsunada, M. S., Bassi, D., Araújo, P., Mattiello, L., Guidelli, G. V., ... Menossi, M. (2017). Sugarcane water stress tolerance mechanisms and its implications on developing biotechnology solutions. Front. Plant Sci., 8, 1077. https://doi.org/10.3389/fpls.2017.01077

Giannopolitis, C., \& Ries, S. (1977). Superoxide Dismutases: I. Occurrence in Higher Plants. Plant Physiology, 59(2), 309-314. https://doi.org/10.1104/pp.59.2.309 
González-Chavira, M. M., Herrera-Hernández, M. G., Guzmán-Maldonado, H., \& Pons-Hernández, J. L. (2018). Controlled water deficit as abiotic stress factor for enhancing the phytochemical content and adding-value of crops. Scientia Horticulturae, 234, 354-360. https://doi.org/10.1016/j.scienta.2018.02.049

Havir, E. A. E., \& Mchale, N. A. (1987). Biochemical and development characterization of multiples forms of catalase in tobacco-leaves. Plant Physiology, 84(2), 450-455. https://doi.org/10.1104/pp.84.2.450

Hellal, F. A., El-Shabrawi, H. M., Abd El-Hady, M., Khatab, I. A., El-Sayed, S. A. A., \& Abdelly, C. (2018). Influence of PEG induced drought stress on molecular and biochemical constituents and seedling growth of Egyptian barley cultivars. Journal of Genetic Engineering and Biotechnology, 16(1), $203-212$. https://doi.org/10.1016/j.jgeb.2017.10.009

Hermann, E. R., \& Câmara, G. M. S. (1999). Um método simples para estimar a área foliar de cana-de-açúcar. STAB, 17, 32-34.

IPA (Empresa Pernambucana de Pesquisa Agropecuária). (1998). In F. J. A. Cavalcanti (Ed.), Recomendações de adubação para o estado de Pernambuco (2nd ed., p. 198). Recife: IPA.

Iqbal, H., Yaning, C., Waqas, M., Shareef, M., \& Raza, S. T. (2018). Differential response of quinoa genotypes to drought and foliage-applied $\mathrm{H}_{2} \mathrm{O}_{2}$ in relation to oxidative damage, osmotic adjustment and antioxidant capacity. Ecotoxicology and Environmental Safety, 164, 344-354. https://doi.org/10.1016/j.ecoenv. 2018.08.004

Jiang, Z., Ma, B., Erinle, K. O., Cao, B., Liu, X., Ye, S., \& Zhang, Y. (2016). Enzymatic antioxidant defense in resistant plant: Pennisetum americanum (L.) K. Schum during long-term atrazine exposure. Pesticide Biochemistry and Physiology, 133, 59-66. https://doi.org/10.1016/j.pestbp.2016.03.003

Jungklang, J., Saengnil, K., \& Uthaibutra, J. (2017). Effects of water-deficit stress and paclobutrazol on growth, relative water content, electrolyte leakage, proline content and some antioxidant changes in Curcuma alismatifolia Gagnep. cv. Chiang Mai Pink. Saudi Journal of Biological Sciences, 24(7), 1505-1512. https://doi.org/10.1016/j.sjbs.2015.09.017

Kar, M., \& Mishra, D. (1976). Catalase, Peroxidase and Polyphenol Oxidase Activities during Rice Leaf Senescence. Plant Physiology, 57, 315-319. https://doi.org/10.1104/pp.57.2.315

Köppen, W., \& Geiger, R. (1928). Klimate der Erde. Verlag Justus Perthes, Gotha, Wall-Map.

Kumar, M., Kumar, R., Jain, V., \& Jain, S. (2018). Differential behavior of the antioxidant system in response to salinity induced oxidative stress in salt-tolerant and salt-sensitive cultivars of Brassica juncea L. Biocatalysis and Agricultural Biotechnology, 13, 12-19. https://doi.org/10.1016/j.bcab.2017.11.003

Kumar, D., Malik, N., \& Sengar, R. S. (2019). Physio-biochemical insights into sugarcane genotypes under water stress. Biological Rhythm Research, 1-24. https://doi.org/10.1080/09291016.2019.1587838

Kuwabara, T., \& Katoh, Y. (1999). Involvement of the binuclear copper site in the proteolytic activity of polyphenol oxidase. Plant Cell Physiology, 40(10), 1029-1035. https://doi.org/10.1093/oxfordjournals. pcp.a029484

Li, C., Li, Y., Li, Y., \& Fu, G. (2018). Cultivation techniques and nutrient management strategies to improve productivity of rain-fed maize in semi-arid regions. Agricultural Water Management, 210, 149-157. https://doi.org/10.1016/j.agwat.2018.08.014

Mansour, M. M. F., \& Ali, E. F. (2017). Evaluation of proline functions in saline conditions. Phytochemistry, 140, 52-68. https://doi.org/10.1016/j.phytochem.2017.04.016

Marcos, F. C. C., Silveira, N. M., Mokochinski, J. B., Sawaya, A. C. H. F., Marchiori, P. E. R., Machado, E. C., \& Ribeiro, R. V. (2018). Drought tolerance of sugarcane is improved by previous exposure to water deficit. Journal of Plant Physiology, 223, 9-18. https://doi.org/10.1016/j.jplph.2018.02.001

Merwad, A.-R. M. A., Desoky, E.-S. M., \& Rady, M. M. (2018). Response of water deficit-stressed Vigna unguiculata performances to silicon, proline or methionine foliar application. Scientia Horticulturae, 228, 132-144. https://doi.org/10.1016/j.scienta.2017.10.008

Moura, B. B., Hoshika, Y., Silveira, N. M., Marcos, F. C. C., Machado, E. C., Paoletti, E., \& Ribeiro, R. V. (2018). Physiological and biochemical responses of two sugarcane genotypes growing under free-air ozone exposure. Environmental and Experimental Botany, 153, 72-79. https://doi.org/10.1016/j.envexpbot.2018. 05.004 
Oliveira, E. C. A. de, Freire, F. J., Oliveira, A. C. de, Simões Neto, D. E., Rocha, A. T. da, \& Carvalho, L. A. de. (2011). Produtividade, eficiência de uso da água e qualidade tecnológica de cana-de-açúcar submetida a diferentes regimes hídricos. Pesquisa Agropecuária Brasileira, 46(6), 617-625. https://doi.org/10.1590/ S0100-204X2011000600007

Oliveira, A. R., Braga, M. B., \& Walker, A. M. (2015). Comportamento vegetativo e qualidade tecnológica de cultivares de cana-de-açúcar submetidas ao estresse hídrico em condições semiáridas do Brasil. Revista Brasileira de Geografia Física, 8, 525-541. https://doi.org/10.5935/1984-2295.20150013

Patade, V. P., Bhargav, A., S., \& Suprasanna, P. (2011). Salt and drought tolerance of sugarcane under iso-osmotic salt and water stress: Growth, osmolytes accumulation, and antioxidant defense, Journal of Plant Interactions, 6(4), 275-282. https://doi.org/10.1080/17429145.2011.557513

Pedroso, L. L. A., Silva, F. F., Silva, F. F., Melo, A. M., Erthal Junior, M., Shimoya, A., ... Souza, C. L. M. (2018). Current and future demands for biomass and renewable energy in Brazil and worldwide. Brazilian Journal of Development, 4(5), 1980-1996.

RIDESA. (2010). Catálogo nacional de variedades “ $R B$ ” de cana-de-acúcar (p. 136). Rede Interuniversitária para o Desenvolvimento do Setor Sucroalcooleiro, Curitiba.

Sales, C. R. G., Ribeiro, R. V., Machado, D. F. S. P., Machado, R. S., Dovis, V. L., \& Lagôa, A. M. (2012). Trocas gasosas e balanço de carboidratos em plantas de cana-de-açúcar sob condições de estresses radiculares. Bragantia, 71, 319-327. https://doi.org/10.1590/S0006-87052012000300001

Scandalios, J. G. (2005). Oxidative stress: Molecular perception and transduction of signals triggering antioxidant gene defenses. Brazil Jornal of Medical Biological Research, 38, 995-1014. https://doi.org/ $10.1590 / \mathrm{S} 0100-879 \mathrm{X} 2005000700003$

Sheikh-Mohamadi, M.-H., Etemadi, N., Arab, M. M., Aalifar, M., \& Arab, M. (2018). Physiological and Ascorbate -Glutathione pathway-related genes responses under drought and heat stress in crested wheatgrass. Scientia Horticulturae, 242, 195-206. https://doi.org/10.1016/j.scienta.2018.07.037

Silva, E. (1981). Estudos da atividade enzimática da polifenoloxidase e da peroxidase em algumas frutas e hortaliças in natura e processadas (Dissertação, Mestrado em Tecnologia de alimentos, Escola Superior de Agricultura de Luiz de Queiroz, Piracicaba).

Silva, G. C., Oliveira, F. J. D. E., Anunciação Filho, Clodoaldo J. D. A., Simões Neto, D. E., \& Melo, L. J. O. T. D. E. (2011). Divergência genética entre genótipos de cana-de-açúcar. Revista Brasileira de Ciências Agrárias, 6(1), 52-58. https://doi.org/10.5039/agraria.v6i1a848

Silveira, L. C. I., Kist, V., Paula, T. O. M., Barbosa, M. H. P., Oliveira, R. A., \& Daros, E. (2012). Adaptabilidade e estabilidade fenotípica de genótipos de cana-de-açúcar no estado de Minas Gerais. Ciência Rural, 42(4). https://doi.org/10.1590/S0103-84782012000400002

Simões, A. N., Moreira, S. I., Mosquim, P. R., Soares, N. F. F., \& Puschmann, R. (2015). Effect of conservation temperature on quality and phenolic metabolism of intact and minimally processed kale leafs. Acta Scientiarum, 37(1), 101-107. https://doi.org/10.4025/actasciagron.v37i1.18123

Tolbert, N. E., Oeser, A., Yamazaki, R. K., Hageman, R. H., \& Kisaki, T. (1969). A survey of plants for leaf peroxissomes. Plant Physiology, 44, 135-147. https://doi.org/10.1104/pp.44.1.135

Urbanek, H., Kuzniakgebarowska, E., \& Herka, K. (1991). Elicitation of Defense Responses in Bean-Leaves by Botrytis-Cinerea Polygalacturonase. Acta Ph ysiol. Plant, 13, 43-50.

Vranova, E., Atichartpongkul, S., VIllarroel, R., Van Montagu, M., Inze, D., \& Van Camp, W. (2002). Comprehensive analysis of gene expression in Nicotiana tabacum leaves acclimated to oxidative stress. Proc Natl Acad Sci, 99, 10870-10875. https://doi.org/10.1073/pnas.15233799

\section{Copyrights}

Copyright for this article is retained by the author(s), with first publication rights granted to the journal.

This is an open-access article distributed under the terms and conditions of the Creative Commons Attribution license (http://creativecommons.org/licenses/by/4.0/). 